\title{
Ganyang! Indonesian Popular Songs from the Confrontation Era, 1963-1966
}

\author{
Steven Farram \\ Lecturer in North Australian and Regional Studies (History) \\ Faculty of Law Business and Arts, Charles Darwin University, Darwin \\ steven.farram@cdu.edu.au
}

\begin{abstract}
Many political policies of Soekarno-era Indonesia were celebrated in popular song. By far the most referenced policy was Indonesia's Confrontation with Malaysia. This article examines the contents of many of those songs and discusses the reasons for their creation and popularity. At the time, the creation of an 'Indonesian identity' based on cultural practices was a matter considered of the utmost importance by Soekarno and his left-wing supporters. This led to frequent public statements against the perils of Western 'cultural imperialism', especially through rock and roll. It is argued, however, that the Left by no means had a monopoly on the propagation of national pride. The Left supported Confrontation, but so did the majority of the Indonesian public; many also liked Western-influenced music and a number of Confrontation songs are not so dissimilar to the popular Western music of the day. Through an examination of some of these songs, referencing popular culture theorists and Indonesian popular culture specialists (both in the fields of music and other areas), it is shown how popular music reflected what was happening in the political arena, and also how songwriters and performers endeavoured to use music to articulate their own social meaning.
\end{abstract}

\section{Keywords}

196os - Confrontation - Indonesia - Malaysia - Popular music - Soekarno 


\section{Introduction}

In 1965, Australian writer Maslyn Williams spent several months in Indonesia. ${ }^{1}$ Wherever he travelled he noted 'an obsessive condemnation of Malaysia'. It began early in the morning with the radio playing first the national anthem and then the 'hate song' Ganjang Malaysia (Crush Malaysia) (Williams 1966:20-1). That song was only one of many that referred to Indonesia's Confrontation (Konfrontasi) with Malaysia, which lasted from 1963 to 1966 and was promoted vigorously by Indonesia's president, Soekarno. Soekarno had great oratorical skills and used his speeches to promote his notion of ongoing revolution and his anti-imperialist, nationalist policies, many of which he condensed into snappy slogans and acronyms. Many Soekarno-era policies were referenced in the popular songs of the day, but Confrontation with Malaysia was easily the most approved policy in terms of the number of songs written and recorded. The content of those songs and the reasons for their popularity are the main concerns of this article.

Examining the question of why Soekarno's political policies featured so strongly in the popular music of the day can provide us with an alternative reading of history. Was it an indication of genuine support for the policies or were there other reasons? Why did some artists record songs that praised Soekarno's policies, even though much of their remaining work seems to be at odds with what was officially approved? And not only why did the artists record those songs, but why were their themes so popular with the Indonesian public? In his 1981 seminal essay, 'Notes on deconstructing "the popular", Stuart Hall argues that 'popular culture' is the result of an ongoing struggle. Shifting power relations and 'the double movement of containment and resistance' are responsible for the resulting cultural content (Hall 1998:442-3). Taking Hall's perspective (and that of other writers who have taken a similar approach) into account when attempting to answer the questions above should provide a better understanding of how the songwriters, singers and listening public were responding to the broader cultural politics of the time. This article will explore these questions through an examination of some of the many popular songs recorded about Confrontation with Malaysia. First, however, in order to place these songs in context, some brief information about Confrontation is provided below.

1 This article uses the Indonesian spelling system adopted in 1972, except for names of people, organizations and songs, which are rendered as they were during the 196os. Thus the Indonesian word ganyang appears in song titles as ganjang. 


\section{Confrontation}

Malaya had achieved independence from Britain in 1957, but Britain was still keen to make some arrangements for the futures of Singapore and its territories in Borneo: Sarawak, Brunei and North Borneo (Sabah). In May 1961, the prime minister of Malaya, Tengku (or Tunku) Abdul Rahman, offered a solution by proposing a federation of Malaya, Singapore and the Borneo territories, and Indonesia raised no objection to the idea. Brunei later decided not to join the federation, but it was a revolt in that territory in late 1962 that seems to have caused Indonesia to change its mind about the Malaysia concept. The revolt, led by A.M. Azahari, head of the Partai Ra'ayat (People's Party), aimed at the creation of an independent state, embracing the three northern Borneo territories, to be called Kalimantan Utara (North Kaliman$\tan$ ) (Legge 1972:361-2). The revolt was short-lived, being crushed swiftly by the British, but in January 1963, Indonesia's Foreign Minister Dr Subandrio declared that it was proof that the planned Federation of Malaysia was being enforced without the people's consent and Indonesia was therefore 'compelled to adopt a policy of confrontation towards Malaya' (Department of Foreign Affairs 1963:176).

In an effort to diffuse the situation it was decided that a United Nations' inquiry would be held to determine the opinion of the people of the northern Borneo territories to the federation, but on 29 August, before the United Nations' mission had been completed, Tengku Abdul Rahman announced that Malaysia would be formed on 16 September 1963 . This was the last straw for Soekarno, who declared that Indonesia would ganyang Malaysia. ${ }^{2}$ By that time Soekarno was convinced that the formation of Malaysia was a neo-colonialist plot that would allow the British imperialists to maintain economic, political and military influence and was thus a threat to Indonesia's sovereignty. Following Soekarno's declaration, the Malayan and British embassies in Jakarta were attacked, British property in Indonesia was seized and Indonesian guerrillas infiltrated Sarawak and Sabah (Legge 1972:365-9).

2 The slogan 'Ganyang Malaysia' is generally translated as 'Crush Malaysia', but ganyang could also mean to 'chew up' or 'devour raw'. The Indonesian words konfrontasi and ganyang are used in Western academic writing almost exclusively in reference to Confrontation with Malaysia. It should be noted, however, that both words were used in a political context for a variety of issues. For example, James Mackie (1974:11) notes that the earlier contest for West Irian was also portrayed as a 'confrontation'; and Rhoma Dwi Aria Yuliantri (2012:429) references an early 1963 speech in which Soekarno urged listeners to ganyang those who opposed his national-unity policies. 
The Indonesian army and the Partai Komunis Indonesia (PKI; Indonesian Communist Party) were vocal supporters of Confrontation with Malaysia; the army because it promised increased budgets and prestige; the PKI because it fitted well with its anti-colonial rhetoric. Confrontation also appears to have struck a strong chord with the Indonesian people as a whole (Legge 1972:364). Compared to other international conflicts, casualties during Confrontation were slight. Nevertheless, over a hundred people were killed on the Malaysian side, and over 500 Indonesians were killed, and even more captured, during the hostilities that came to be known as 'the undeclared war' (Mackie 1974:237). Although Indonesia had not declared war against Malaysia, Confrontation occupied a huge place in the public arena in Indonesia until it was finally wound back following the fall of the PKI and the sidelining of Soekarno after the so-called coup attempt in late 1965. Army support had by then dissipated, but it was still not until 16 August 1966 that an agreement was reached between Malaysia and a newly pro-Western Indonesia to end hostilities and normalize relations between the two countries (Mackie 1974:322).

\section{Popular Songs Inspired by Soekarno's Policies}

Confrontation with Malaysia inspired more popular songs than any other Soekarno-era policy. Nevertheless, it is worthwhile mentioning other Soekarno policies that inspired popular songs in order to demonstrate that songs related to current political issues or affairs were not unusual. Many of the ideas Soekarno presented to the Indonesian people through his speeches became official government policy and parts of everyday speech. For example, Soekarno's 1959 Independence Day address, in which he explained his concepts of Guided Democracy $^{3}$ and ongoing revolution, was subsequently declared to be the Manifesto Politik (Manipol; Political Manifesto) of the Republic of Indonesia, serving as the basic outline of national policy. ${ }^{4}$ Similarly, the concept of

3 Guided Democracy effectively ended liberal democracy and placed Soekarno in the position of supreme authority. For a detailed discussion of the issues and the main players, see Legge 1972:279-336.

4 Manipol was frequently linked with the acronym USDEK, standing for the 1945 Constitution, Indonesian Socialism, Guided Democracy, Guided Economy and Indonesian Identity (Undang-Undang Dasar 1945, Sosialisme Indonesia, Demokrasi Terpimpin, Ekonomi Terpimpin, Kepribadian Indonesia), matters referred to frequently in Soekarno's speeches; see Legge 1972:332. 
NASAKOM (Nasionalisme, Agama, Komunisme; Nationalism, Religion, Communism), resulting from Soekarno's belief that the main streams in Indonesian life needed to be united for the good of all, became accepted as the ideal model for all social and political activity (Weatherbee 1966:40-1). The concept NEKOLIM (Neo-Colonialist and Imperialist), which Soekarno used to characterize the former European colonial powers and other states of the West (Weatherbee 1966:23), was frequently referenced in the press and elsewhere. Another example is Soekarno's concept of the Panca (or Lima) Azimat Revolusi (Five Talismans of the Revolution) introduced in 1965, which brought together five new and old aspects of his thinking. ${ }^{5}$

Manipol, NASAKOM, NEKOLIM, the Panca Azimat Revolusi and other concepts introduced by Soekarno were referenced in many popular songs of the day. For example, Manipol is mentioned favourably in Lilis Surjani's song Untuk PJM Presiden Sukarno (For His Excellency President Soekarno; written by Soetedjo). ${ }^{6}$ Another example is the song NASAKOM bersatu (NASAKOM unite; written by Subronto K. Atmodjo). ${ }^{7}$ NEKOLIM, in the meantime, is referenced negatively in Lilis Surjani's Pantun djenaka (Funny verse; written by M. Sani) and also in the song Bersuka ria (Be cheerful), recorded by Orkes Irama, with songwriting credited to Soekarno himself. ${ }^{8}$ As a final example, there is Rossy's song Lima azimatku (My five talismans; written by Wedhasmara), which concerns the virtues of the Panca Azimat Revolusi and the overriding need to destroy NEKOLIM in order to save the country.

5 The Panca Azimat Revolusi were: Pancasila (the Five Principles of the state, first announced by Soekarno in 1945); Manipol-USDEK; NASAKOM; Tri Sakti (the Three Sacred Formulae: Political Sovereignty, Economic Self-Reliance and Cultural Identity); and Berdikari (Berdiri di atas kaki sendiri, that is, to stand on one's own feet, or self-reliance); see Tan 1967:1805 .

6 The song, as its title suggests, is one of praise for the president. Other songs about Soekarno include Rossy's Dirgahayu Bung Karno (Long live Bung Karno; written by Wedhasmara); and Onny Surjono's Bung Karno djaja (Glorious Bung Karno; written by Mus K. Wirya). Bung Karno (Elder Brother Karno) was an affectionate nickname for Soekarno.

7 A song about a related concept, Re-So-Pim (Revolusi, Sosialisme, Pimpinan Nasional; Revolution, Socialism, National Leadership), was also written by Subronto K. Atmodjo; both were recorded by Orkes Kutilang and Ansambel Gembira. The two songs were also made compulsory to be taught and sung at schools throughout Indonesia; see Harian Rakjat, 11 January 1965 .

8 The song is credited 'galian/tjiptaan Bung Karno'; that is, 'discovery/creation Soekarno', echoing Soekarno's earlier suggestion that he was a mere vehicle for ideas from a higher source; see Legge 1972:316. 
In the ensuing sections of the article the results of a survey of various Confrontation songs are presented, examining some of their main themes and features. This is followed by a more detailed analysis of the reasons for the popularity of Confrontation songs with performers, songwriters and the listening public. The last part of the article is also concerned with examining how those songs fitted into the general political and cultural landscape of the times.

\section{Popular Songs about Confrontation}

When it comes to songs about Confrontation with Malaysia, there are more than enough examples, with over fifty such songs currently identified by the author. There are several other songs that appear to refer to Confrontation, but which are not considered here because of doubts about recording and release dates. ${ }^{9}$ One song about which there is absolutely no doubt, however, is Ganjang, performed by the Simanalagi choir and orchestra. It was most likely this song that Maslyn Williams heard each morning on the radio (referred to at the beginning of the article).

Ganjang appeared with three other songs closely related to the anti-Malaysia campaign, all written by Jules Fioole. The record cover features a cartoon of three charging soldiers and the title of the feature song: Ganjang. The military theme of the cover is reflected in the music of Ganjang, which is similar to a military marching song. Ganjang is unusual in that it explicitly identifies the enemy as the prime minister of Malaysia, Tengku Abdul Rahman. It does, however, imply that he is just part of the larger NEKOLIM problem.

\section{Ganjang}

Bersiaplah Tengku aku datang menentang maksudmu Hadapilah Tengku aku akan merintang niatmu

Semangat bangsaku 'kan membara setiap penjuru

Kita berjuang membela keadilan di dunia

Kita menuntut merdeka bagi semua bangsa

Bangkitlah serentak Afrika Asia

9 Dating Indonesian records can be difficult. Most Indonesian Confrontation songs appear on the commercial Irama and Remaco labels, but there are currently no authoritative discographies of 196os Indonesian music available apart from the one produced by Philip Yampolsky for the state-owned Lokananta label; see Yampolsky 1987. 


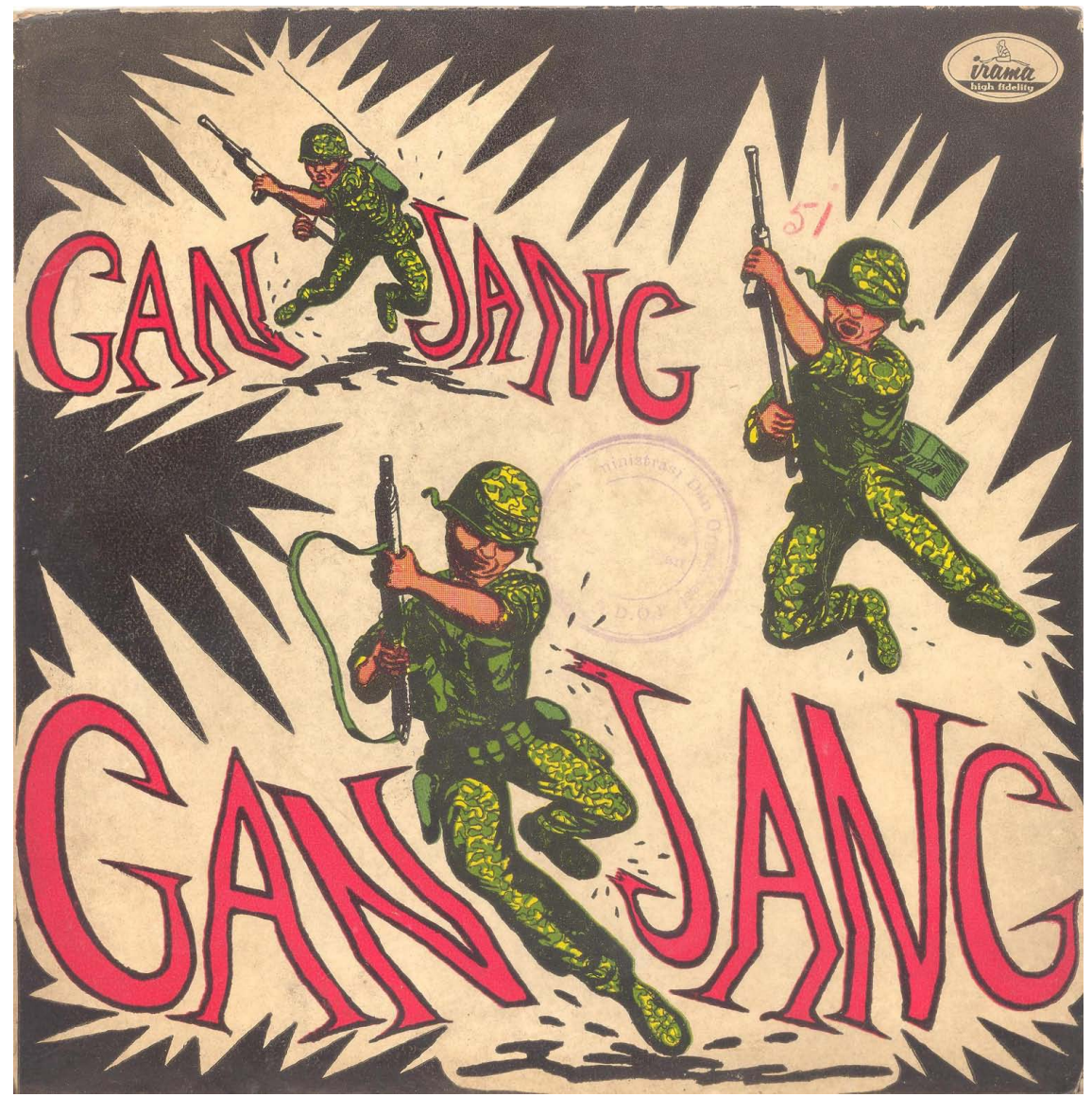

FIGURE 1 Cover of Simanalagi's record featuring the song Ganjang, Irama EP-121; author's collection

Be prepared Tengku, I am coming to obstruct your plans

Face up Tengku, I will block your intentions

The enthusiasm of my nation will set alight every corner

We fight to defend justice in the world

We demand independence for every nation

Rise up [together] Africa and Asia ${ }^{10}$

10 Asia-Africa solidarity had been a feature of Soekarno's rhetoric since the 1955 Asia-Africa Conference held in Bandung. However, most Asian and African leaders did not support Indonesia's Confrontation policy; see Legge 1972:369-70. 


\section{Confrontation Songs that Mention Malaysia}

Surprisingly few of the Confrontation songs are explicit about who is fighting who, or where. There are many songs that talk about fighting 'over there', on the 'front line', or at the 'field of battle'. There are others that mention the 'border', some in the title, such as Rachmat Kartolo's Pesan dari perbatasan (Message from the border; written by Aswin R). At that time Indonesia had three land borders: with Portuguese Timor, with the Australian mandated territories of Papua and New Guinea, and with Malaysia in Borneo. As the only hostilities occurring at the time were in Borneo, it is clear what is intended. A few songs are more explicit: Ansambel Gembira recorded Dari rimba Kalimantan Utara (From the jungles of North Kalimantan; written by Muchtar Embut);1 Karsono Bersaudara recorded the self-penned Ke Kaltara (To North Kalimantan); and Anna Mathovani, in Di keheningan malam (In the quiet of the night; written by Wijarsih), sings that she is praying to God for her hero who is in the jungles of North Kalimantan. The male group Trio Parsito recorded the same song, but called it Kalimantan Utara. Trio Parsito also recorded the song Balada Dwikora (Ballad of Dwikora; written by Djauhari), in which the singers urge all to go forward, never retreat and smash the enemy. Indonesians hearing the song would have known that Dwikora referred to the Dwi Komando Rakyat (the People's Twofold Command), ordered by Soekarno in May 1964: 1. Intensify the defence of the Indonesian revolution; and 2. Assist the struggle of the people of Malaya, Singapore, Sarawak, Brunei and Sabah to dissolve the puppet state of Malaysia. Soekarno announced Dwikora in Jakarta to a rally of volunteers, who had been recruited in large numbers since the previous month (Mackie 1974:244).

\section{Songs about Volunteers}

In April 1964, Malaysia announced the imminent conscription of 100,000 young men to help in the struggle in Borneo, but the move was mainly symbolic, as no more than a few thousand could be absorbed into the existing Malaysian army. Soekarno responded by proclaiming a general mobilization of volunteers that soon claimed a membership of twenty-one million, thus far outnumbering the Malaysian effort. ${ }^{12}$ There are a few songs that highlight the role

\footnotetext{
11 Yuliantri (2012:445) reports the song was recorded in 1963 during a tour of China, North Korea and North Vietnam.

12 Mackie 1974:229-30, 244. Mackie declares the numbers to be fairly meaningless, as mass
} 
of Indonesian volunteers in the conflict, such as Karsono Bersaudara's selfpenned Sukarelawan, which portrays volunteers advancing enthusiastically towards the frontline, prepared to crush the enemy. One of the most aggressive of all Confrontation songs is Orkes Kutilang and Ansambel Gembira's Madju sukarelawan (Advance volunteers; written by Sudharnoto), a military marching-style song in the vein of Simanalagi's Ganjang. We are told there that the volunteers include workers, farmers, youth and others, lined up with their rifles and bayonets ready to fight against evil imperialism. In fact, they dare the enemy to attack so that they can smash them. ${ }^{13}$ James Mackie (1974:244), however, concludes that very few volunteers ever got near the battle zones, with the majority assigned to local military commanders to perform various duties, often with little connection to Confrontation. I Nyoman Darma Putra (2012:328-9), in the meantime, states that in Bali 15,000 volunteer fighters were reported in May 1964 to be ready to depart for North Kalimantan, but a former volunteer asserts that they never actually left the island.

The campaign to recruit volunteers was promoted actively in the press. Soekarno's daughter Megawati was one of the first to enrol, inspiring mass enrolments from student groups (Mackie 1974:244). Male volunteers (sukarelawan) and their female counterparts (sukarelawati) were honoured by being depicted on a new run of banknotes, but the low denominations they appeared on $(5,10$, 25 and 50 sen), combined with the prevalent runaway inflation, meant the notes were virtually valueless and it seems they may never have been released. ${ }^{14}$

organizations and political parties enrolled their entire membership. He concedes, however, that there were, no doubt, large numbers of patriotic individuals who volunteered of their own accord.

13 The lyrics in Indonesian and English are given in Yuliantri 2012:436. Instrumental versions were recorded by Zaenal Combo and J. Koesnoen dan kawan-kawan (J. Koesnoen and friends). The latter appeared on a record on the Lokananta label with three other marching tunes: Menudju medan perbatasan (Approaching the border battlefield; written by Dewo Muljo), NASAKOM bersatu and Indonesia tetap merdeka (Indonesia forever free; written by C. Simundjuntak). Yampolsky notes an instrumental version of Madju sukarelawan also recorded by Drumband Çanka Lokananta, Akademi Militer Nasional, Magelang. He also notes two other bands that seem to have been led by the same J. Koesnoen mentioned above (noted in Yampolsky as J. Kusnan and Jusapan K), and who recorded what appear to be further Confrontation songs: Gema Dwikora (Reverberations of Dwikora; written by Leby/Metty), S'lamat berdjoang untukmu (Have a good fight; written by Jeka), Rindukan pahlawan (Longing for a hero; Jeka) and Kasih di perbatasan (Love at the border; Jeka). These songs appear to be the entire output of Confrontation songs on the national label; see Yampolsky 1987:119, 136, 149, 150. 


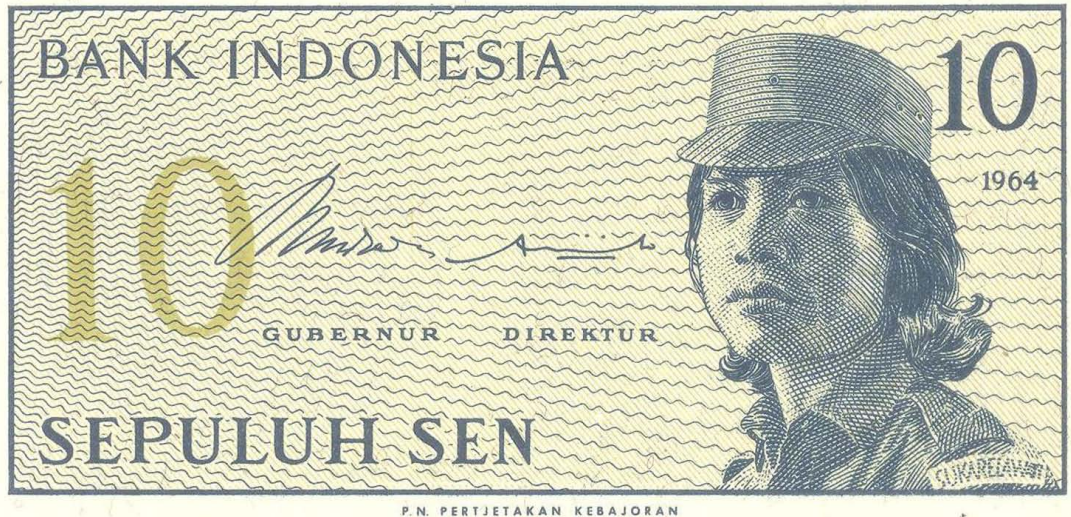

FIGURE 2 Bank Indonesia 10 sen banknote, 1964; author's collection

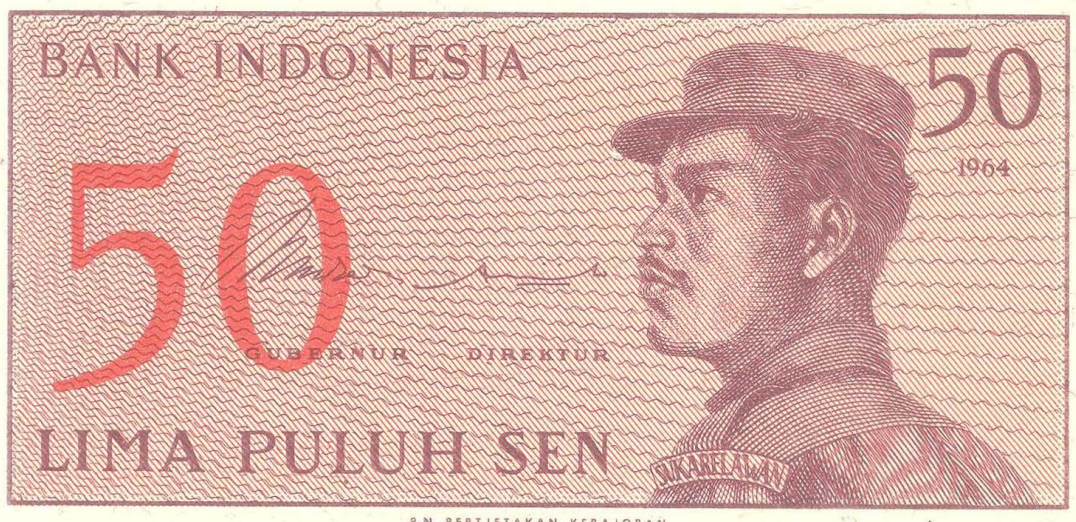

FIGURE 3 Bank Indonesia 5o sen banknote, 1964; author's collection

The sukarelawati received their share of attention in other spheres, however. Putra (2012:330-31) recounts a short story published in a Bali newspaper concerning a sukarelawati who had gone to the battlefield in North Kalimantan and managed to gun down five of the enemy. Less dramatically, Piri Bersaudara's Sukarelawati (written by M. Jusuf), is the Piri sisters' simple song of praise to

recalled that 1 and 5 sen coins were even spurned by beggars; see Bowden 1987:106. In 2013 the notes were readily available in uncirculated condition from numerous dealers worldwide. The series also included a 1 sen note depicting a peasant farmer. 
the women volunteers who have gone forward to defend the nation. The short story and the song may have been useful means of expressing nationalist pride and revolutionary zeal, but, as with their male counterparts, it seems that most female volunteers never even got to Kalimantan, let alone the frontline. In fact, from September 1963, the troops involved in raids into Malaysian territory were said to be mainly 'volunteers' from Indonesian army units, but as the conflict wore on, Indonesia made little effort to deny that regular army forces were involved (Mackie 1974:211, 216).

\section{Songs about Women}

The Indonesian armed forces today have special units for women, but they are excluded from combat roles. In the 196os, Indonesian women's participation in military activities was even more limited. There are no indications that any women volunteers or female members of the armed forces were involved in frontline activities in Kalimantan during Confrontation. Yet there are a number of popular songs that portray women doing just that. For example, it has already been mentioned that Anna Mathovani's Dikeheningan malam was also recorded by the male group Trio Parsito with the title Kalimantan Utara. With male vocals, the implication is that the loved one in the North Kalimantan jungle who is the subject of the song is female. Possibly Rachmat Kartolo's song Rela (Acquiesce; written by Albert Tan), which concerns a loved one who has gone to 'the front', was also originally meant to be sung by a woman. Lilis Surjani, however, recorded a number of songs in which she is the one going to 'the front' to fight the enemy, and as two of those songs, Pergi berdjoang (Going to battle) and Tiga malam (Three nights), were written by Surjani herself, there is no doubt what the songwriter's intention was. ${ }^{15}$

With her album Doa ibu (A mother's prayer), Titiek Puspa gives an indication of the purpose of Confrontation songs that placed women at the forefront of the action. The album has several songs with nationalist themes, mainly written by Puspa herself. The title track is about a mother praying that her child will fulfil its duty to the nation. Some songs seem more directly related to Confrontation, such as Pantang mundur (Never retreat), an entreaty to the fighters at 'the front'. In Ku ingin djadi Srikandi (I want to be Srikandi), however, Pupsa sings of the heroic wayang figure Arjuna, and expresses her wish that she

15 Perhaps surprisingly, Surjani's Pergi berdjoang was also released in Malaysia and appears to have been quite popular. 
was his wife, Srikandi, who was renowned for her own martial skills and feats. Sjaiful Nawas writes in the liner notes for the album that with the song Ku ingin djadi Srikandi 'Titiek shows that she does not want to sit with her hands in her lap during this time of struggle, when the revolution has yet to be completed' Nawas says of the album as a whole that 'with the making of the songs in this LP Titiek has fulfilled her duty as a progressive-revolutionary artist'. Thus we can read these female-centred Confrontation songs as an attempt to show that all Indonesians, men and women, wished to contribute to the overthrow of the 'puppet state' Malaysia. That women did not actually fight in Kalimantan was as inconsequential as the fact that volunteers did not either. As the Balinese volunteer who never left his island said, the important thing was the overall show of force and the inherent threat this contained for Malaysia. ${ }^{16}$

\section{Songs about Men}

More realistically, most Indonesian Confrontation songs are about men in the army. Karsono Bersaudara released an album of mostly self-penned songs, Pahlawanku (My hero), that was dedicated entirely to men fighting at 'the front' and performing their 'sacred duty' to defend the nation. Many Indonesian Confrontation songs are by women about their menfolk who are defending the homeland, such as Lilis Surjani's self-penned Kau pembela nusa dan bangsa (You, defender of the homeland); Diah Iskandar's self-penned Kita pasti menang (We will surely win); and Tiga Dara Sitompul's Madjulah pahlawan (Advance hero; written by P. Sitompul). A number of songs by women are about men who have died defending the nation, including Jetty Moersidik's Bhakti pertiwi (Service to the homeland; written by Adikarso); Titiek Puspa's self-penned Namamu selalu (Your name always); Salanti Bersaudara's Untuk pahlawan (For a hero; written by Alfian); Tuty Subardjo's Semoga ke Nirwana (Hopefully to Nirwana; written by Mus K. Wirya); and Lilis Surjani's Berita (News; written by Titiek Puspa).

16 Putra 2012:329. The idea that a song in itself could contribute all that was required in the service of the country was best expressed in Novel's self-penned Sumbangan bhaktiku (My loyal contribution), in which he says simply that he wants to contribute to the struggle of his beloved Indonesia and he hopes that his song can be accepted as his contribution. 


\section{Confrontation Songs and the Political Landscape}

Having surveyed some of the many Confrontation songs, it is time to consider how they fitted into the political landscape of the time. Hall $\left(1998: 442-4,45^{2}\right)$ argues that 'popular culture' is the outcome of an ongoing struggle between 'the people' and 'the dominant ideology' - 'popular culture' versus the 'culture of the power bloc'. Thus, if we wish to understand why certain political policies were praised in popular songs, it is necessary to comprehend the cultural politics of the day and the way the struggle over 'popular culture' took place. One problem, as Hall (1998:452) recognizes, is defining 'the people'; he concludes that there is no single entity to fit the label-the answer to the question in 1960 s Indonesia was no easier. Arguing from a socialist perspective, Hall has no problem with the other half of his equation: the 'power bloc' or 'dominant ideology' is capitalism. In Confrontation-era Indonesia, however, the issues were more complicated. The main public commentators on cultural matters were Soekarno, who repeatedly called for the creation of a national culture and the rejection of Western 'cultural imperialism', and his supporters, especially the PKI and its associated cultural organization, the Lembaga Kebudajaan Rakjat (LEKRA; Institute of People's Culture), whose slogan 'Politics is the Commander' informed its insistence on socially committed cultural production. Part of LEKRA's challenge was to overcome old elitist notions of 'legitimate culture', but the main public opposition to the LEKRA position ultimately came from the signatories of the Manifes Kebudajaan (Manikebu; Cultural Manifesto), a group of writers, artists and intellectuals who called in August 1963 for a national culture that was not aligned to any particular political ideology. ${ }^{17}$ The Manikebu affair will be examined further below, but first the contest for the creation of a 'national music' will be discussed.

\section{The Contest over 'National Music'}

In his 1959 Independence Day speech, Soekarno praised Indonesian youth for their opposition to economic and political imperialism, but asked why they did not oppose cultural imperialism. Why did they support rock and roll and cha-cha-cha, he asked; why did they like 'crazy' music? The government, he

\footnotetext{
17 Bodden 2010:46, 62. Manikebu was an abbreviation created by the PKI intended to be derogatory, as it can also mean 'water-buffalo sperm'. However, over time the term has become the accepted shorthand for the document.
} 
said, would protect national culture, but the youth must protect and develop it as well (Soekarno 1959:39). LEKRA was of the same mind and at its first national congress, held in January 1959, it was reported that Western music was becoming popular with Indonesian youth, but that such music was generally 'sensational', containing either 'empty sentimentality' or the 'hysterics' of 'boogie-woogie' and 'rock and roll'. In order to help offer an alternative to this 'inferior' music, LEKRA co-operated with workers, students, farmers, women and youth to organize musical events and establish music and singing groups (Soedharnoto 1959).

At its 1961 plenary session, and again at its 1962 national congress, LEKRA concluded that it must double its efforts to create a national music, as the 'hysterical' and 'pornographic' music heard on imported phonograph records continued to be popular. Not only was this 'imperialist' music popular, there was also a growing number of Indonesian bands whose music was identical with that which LEKRA wished to banish (Ajoeb 1961; Ajoeb 1962). Things were no better by 1964, when author Pramoedya Ananta Toer told LEKRA's plenary session that popular Indonesian songs were identical with those from the United States of America (USA) and were all about sex. Pramoedya complained that while such 'unrealistic', 'counter-revolutionary' music was easily available, genuine revolutionary and patriotic music was rarely heard (Toer 1964). Conforming to Soekarno's concerns to promote 'national identity', LEKRA turned to regional music genres to help create a 'national music'. However, in line with its general ideology, LEKRA argued that regional music must be transformed with 'revolutionary themes'. Using the unique rhythms to be found in regional music, it was argued, would create songs that would be sung for years to come. Songs based on rhythms 'made in the USA', however, would quickly be forgotten (Yuliantri 2012:428-9).

LEKRA encouraged music and dance ensembles in various regions to promote local music genres and to help crush 'crazy' Western popular music and dance styles like the twist. These ensembles travelled widely and proved to be very popular. The Angin Timur (Eastern Wind) ensemble was established by LEKRA in Pontianak, West Kalimantan, where it was reported to have entertained volunteers in the Confrontation campaign and also Indonesian troops on the frontline (Yuliantri 2012:440-1). Most ensembles, however, were established independently. One of the most popular of such groups was the chorus Ansambel Gembira, which was invited often to perform at state functions and performed frequently for the national radio network (Yuliantri 2012:448). Gembira and other groups were also sent overseas as members of cultural missions, usually to socialist countries. It was on such a mission to East Asia that Gembira recorded the song Dari rimba Kalimantan Utara (noted earlier) (Yuliantri 
2012:445). Gembira also contributed the vocals to an album full of songs with a nationalist theme, including the already mentioned NASAKOM bersatu, Re-SoPim and Madju sukarelawan. ${ }^{18}$

The known recorded output of the ensembles approved by LEKRA is quite small compared to the commercial releases of songs with nationalist themes from other artists, inviting the question: which was the genuine 'popular music'? LEKRA was the self-appointed champion of 'the people', but the types of music it did not approve were very popular. Nevertheless, the repeated statements by Soekarno, LEKRA and others against cultural imperialism eventually took its toll. The antipathy to rock and roll reached its ultimate expression with the imprisonment without trial of the members of the group Koes Bersaudara in June 1965; their 'crime' had been playing Beatles' songs. ${ }^{19}$ Other performers got off more easily, but some were challenged and made public statements to clear their names. For example, Lilis Surjani declared in a newspaper article that she had previously sung in the style of the Beatles, but she had only been following trends. She had only become aware of the error of her ways after reading about the efforts to 'stamp out' 'Beatles-like' songs and she would not repeat her mistakes. Surjani had, however, made her amends and was praised for having recently recorded a number of songs suited to Indonesian 'national identity', including the afore-mentioned Untuk PJM Presiden Sukarno. ${ }^{20}$ That song was set to music suitable for the lenso, a social dance from eastern Indonesia, which was much favoured by Soekarno. Surjani even recorded a song entitled Mari berlenso (Let's do the lenso; written by Mus Mualim). The song contains the words "This is the rhythm of the lenso, the rival of the crazy "shake" and the "twist". It is not excessive and is true to [Indonesian] identity'.

Surjani recorded several songs that referred to Confrontation and her devotion to nationalist ideals appears to have gone unquestioned. However, some of her songs at least verged on rock and roll and were not vastly dissimilar to Western pop songs of the period; for example, her song Pergi berdjoang already

18 The long-playing album Satu Nusa Satu Bangsa was recorded with Orkes Kutilang and appeared on the Irama label. My thanks to Henk den Toom, who made the album available via his Madrotter blog. Gembira made at least one other recording for Irama, appearing with the Empat Sekawan orchestra for four children's songs. Yampolsky (1987:110) notes one Gembira long-playing album on the Lokananta label.

19 Koes Bersaudara wrote their own songs in Indonesian and their records were very popular. They did not, however, record any songs on a political theme during the Confrontation era. Rather, their music was similar to Western-style love songs. For more on the case of Koes Bersaudara, see Farram 2007.

20 Kompas, 20 August 1965. 
mentioned. The same could be said for songs by several other artists, such as Onny Surjono's Ikhlaskan (Accept with sincerity; written by M. Jusuf), about a man seeking blessings as he goes to defend the nation, and Bambang S's Berilah restumu (Give me your blessing; written by Sjamsuddin), on the same theme. Furthermore, the songs on the album Pahlawanku by Karsono Bersaudara do not sound radically different from the style of music played by Koes Bersaudara, and the liner notes for the album even compare the two groups favourably. Yet Pahlawanku was released at about the same time that Koes Bersaudara was jailed for playing rock and roll.

Part of the problem for LEKRA and others who campaigned for the creation of a 'national music' in early 196os Indonesia was to define what it meant: what music was appropriate to 'national identity' and what was not? After seeking the assistance of cultural groups to answer these questions, the Ministry for Education and Culture was able to provide some clearer definitions. As reported in the press in August 1965, certain types of music were thenceforth to be considered 'destructive' and fought against until eliminated. Music in this category had characteristics such as: a beat giving the impression of uncontrolled behaviour, incompatible with Indonesian identity; lyrics containing exaggerated expressions of love or giving rise to sexual desire; strange singing that is half shouted; and music performances where the presentation, clothing or other features followed foreign styles that do not conform to Indonesian tastes. ${ }^{21}$ Defining 'national music' by reference to undefined notions such as 'Indonesian identity' and 'Indonesian taste' was bound to be problematical and was not a great advance on the existing vague proscription against 'Beatleslike' music. Clothing and hairstyles were regulated (Farram 2007:225-6), but it seems that if those matters were in order and the lyrical content of songs was in accordance with the prevailing political policies, the actual music was not subject to scrutiny; at least it appears these songs were not subject to public condemnation. Possible reasons for this are considered in the next section.

\section{Why Was Western-influenced Music Tolerated?}

In Hall's (1998) analysis the 'dominant ideology' that wishes to control popular culture is capitalism. In the context of Confrontation-era Indonesia this was expressed through Soekarno's and LEKRA's fear of Western cultural imperialism. However, Soekarno and LEKRA had a shared vision of elevating regional

21 Kompas, 24 July and 18 August 1965. 
musical traditions to become the basis of the new 'national music'. Some of those traditions were of the 'folk' variety and did not belong in the realms of 'high art', as it was understood in the existing elitist approach to culture. LEKRA's insistence on the incorporation of 'progressive' messages was a further challenge (Lindsay 2012:16-7). Thus, the existing local 'high culture' also needed to be overcome if the new 'revolutionary' forms were to be accepted as 'legitimate culture'. Lawrence Grossberg is in general agreement with Hall's analysis and wants to defend popular culture against those who measure it against 'high' or 'legitimated' culture. On the other hand, he sees no value in opposing popular culture to 'legitimate' culture and accepts (albeit somewhat begrudgingly) that 'high' culture could be popular culture for some (Grossberg 1997:2-7). LEKRA certainly did not reject Indonesia's classical music traditions as part of 'national identity', but it turned to more 'popular' styles of music as the vehicle for its progressive messages. Craig Lockard reports that in late 199os Indonesia, popular music was not taken seriously by the cultural establishment. He points out, however, that popular music is immediate, can be reflective of everyday life, and is a very effective means of communication (Lockard 1998:9-10). One assumes it was precisely for these reasons that LEKRA favoured popular music for its purposes.

LEKRA sought to 'revive' regional music with new arrangements and progressive lyrics, but, as Yuliantri (2012:435) points out, the ideal became patriotic songs using a spirited 'march' rhythm. The songs by Gembira and Orkes Kutilang, already noted, belong to this category, as does Simanalagi's Ganjang. Considering LEKRA's opposition to cultural imperialism, the choice of this European music genre may seem surprising; from its very beginning in 1950, though, LEKRA had stated that it had no objections to foreign cultures and that it would draw freely on any of their 'progressive' aspects (Yuliantri 2012:423-4). Clearly LEKRA considered march music to belong to this category and by accepting it as a vehicle for expressing nationalist sentiments it was signalling that it did not consider it to be a threat to national identity or national music. As Roy Shuker, however, points out, to argue against cultural imperialism it is necessary to believe there is a distinctively national music that will suffer if not protected. By LEKRA's own account an Indonesian national music did not yet exist. Moreover, Shuker says it can be argued that since the 1950s, Anglo-American culture has become the international youth culture, especially rock and roll. Nevertheless, he believes that local musical traditions have been absorbed in the process, creating a hybrid form of music (Shuker 1994:61-2). Brian Longhurst (2002:512) takes this further, arguing that what is referred to as Western popular music is really a mixture, with much of it based on African forms and other influences; thus it is already part of transnational culture. 
Grossberg (1997:15), in the meantime, speaking of his approach to music, says he is more interested in music's political possibilities rather than questions of authenticity. Prince Norodom Sihanouk of Cambodia appears to have felt the same way, as he supported the modernization of his country's arts through the adoption of foreign influences. Sihanouk was a friend and supporter of Soekarno, but the two leaders chose quite different ways to create new modern societies for their countries. While Soekarno and LEKRA vented their spleens about rock and roll and other foreign musical influences, in Cambodia such additions were welcomed. Cambodian rock and roll of the 196os featured up-tempo rhythms combined with traditional singing styles and Khmer lyrics about typically local topics (Saphan 2013:4). The result appears to have been uniquely Cambodian. The same is true of a lot of 1960 os Indonesian music that incorporates foreign musical styles, such as cha-cha-cha and rock and roll, but remains distinctly Indonesian. It is possible that LEKRA realized by the mid1960 s that it had painted itself into a corner with its unsustainable opposition to external musical influences and remained silent as long as the result satisfied its other political criteria. It is also quite likely that many LEKRA members, especially the younger ones, did not share their organization's stated antipathy to rock and roll.

\section{Why Did Indonesian Performers and Songwriters Support Confrontation?}

A cynical response to the question of the popularity of the Confrontation theme is that the artists mentioned in the preceding sections merely recorded songs in accord with Soekarno's policies in order to ingratiate themselves to the regime. By doing so they could continue to write and sing the sorts of songs they really preferred without fear of incurring the displeasure of the authorities. The incarceration of Koes Bersaudara stressed the possible dangers of doing otherwise, but many of the songs mentioned in this article were recorded well before that event, which occurred in the last phase of Soekarno's rule. Another problem with this argument is that most of the songs mentioned here were very popular with the public.

At this point, it is useful to consider the Cultural Manifesto (Manikebu) affair, mentioned earlier. The document was made public in August 1963, with the signatories consisting of sixteen writers, three painters and one composer. The group sought a national culture unaligned to any particular political ideology. Soekarno's political slogans dominated public discourse at the time and were repeated over and over again. Goenawan Mohamad (2011:4), one of the 
Manikebu signatories, says the result was that the meaning of words such as 'workers', 'peasants', 'the people', 'the motherland' and 'freedom' became increasingly abstract and it became difficult to write in an original way. However, in order to show their 'revolutionary credentials', people felt compelled to repeat Soekarno's slogans. Moreover, according to Mohamad 'the excitement of the period' and 'the "revolutionary" inspiration' caused, first, by the campaign for the liberation of West Irian; second, by the Asian Games in Jakarta, where Indonesian athletes performed exceptionally well; and finally, in 1963, by Confrontation with Malaysia, raised people's feelings of nationalism to fever pitch. In that atmosphere 'many writers of various political persuasions', including Mohamad, felt inspired to create works with themes such as 'the motherland', 'the masses' and 'the people' (Mohamad 2011:4-5).

According to Mohamad not one Manikebu signatory was anti-Soekarno. Indeed, many parts of the document quote Soekarno and refer to his concepts. Nevertheless, this was not good enough because Manikebu clearly rejected LEKRA's insistence on the central importance of politics in art, viewing this as dehumanizing and a barrier to creating anything of aesthetic quality (Mohamad 2011:19, 38). Inevitably, LEKRA and the PKI denounced Manikebu and its signatories as 'counter-revolutionary'. On 8 May 1964, Soekarno announced Manikebu had been banned, arguing that Manipol had been declared the basic outline of national policy and there was no possibility of it being accompanied by any other manifesto, especially if it appeared to show 'a hesitant attitude towards the Revolution' (Foulcher 1969:444-5). Despite the ban, LEKRA and the PKI did not decrease the pressure, and the Manikebu signatories found they could no longer publish their writings. Those employed by the government were sacked and an atmosphere of fear prevailed amongst all who had signed or supported Manikebu (Mohamad 2011:2-3).

Manikebu spoke of the arts in a general fashion, but all examples used to support its arguments were taken from the field of literature; there was no specific mention of music. Binsar Sitompul, the sole composer listed as a Manikebu signatory, today occupies a special place in Indonesian national culture as cowriter of the obligatory (wajib) national song Bhinneka tunggal ika.$^{22}$ His immediate fate following the Manikebu affair is unclear, but other composers, musicians and performers would have been in no doubt that their own creations and performances were closely scrutinized by the self-appointed guardians of national culture, LEKRA and the PKI, as they had been vocal on such matters

\footnotetext{
22 'Bhinneka Tunggal Ika' is the motto on the national coat of arms, usually translated as 'Unity in Diversity'.
} 
for years. As the Manikebu affair coincided with the intensification of Confrontation with Malaysia, can it be assumed Indonesian songwriters and performers were merely protecting themselves by recording songs related to this policy?

Mohamad (2011:4) recalls the period as one of continual calls to undertake indoctrination programmes in the 'teachings of Bung Karno'. Mackie also mentions indoctrination in the official ideology as one of the main features of the era. However, he argues that most Indonesians accepted what he called 'Soekarno's millenarian fantasies' because there appeared to be no other solutions to Indonesia's deep-seated economic and political problems. Mackie also says that Soekarno had an uncanny ability to feel the mood of the people and to arouse their 'enthusiasm and a sense of personal identification with the national struggle' (Mackie 1974:18, 81, 92). Michael Bodden, in the meantime, writing about LEKRA theatre productions in North Sumatra in the 1950s-6os, notes that while there was often fierce criticism traded between leftist-groups and their opponents during those times, there were also a number of points of congruence, not the least of which was an intense commitment to the Indonesian nation and national identity. Bodden argues that under Guided Democracy public political discourse became bound to these ideas and the contest between opposing groups was often expressed in terms of who could proclaim their nationalist credentials most loudly (Bodden 2010:49-50).

Bodden also notes that the North Sumatran LEKRA theatre groups did not work in isolation and often cooperated with other groups who would otherwise appear to have been their political opponents, such as LESBUMI (Lembaga Seniman Budajawan Muslimin Indonesia, Institute of Indonesian Muslim Artists and Cultural Workers; associated with traditionalist Muslim party Nahdlatul Ulama) and LKN (Lembaga Kebudajaan Nasional, Institute of National Culture; associated with the Partai Nasional Indonesia, Indonesian National Party). ${ }^{23}$ Putra (2012), meanwhile, shows that LEKRA in no way had a monopoly on 'revolutionary' policies, as on Bali, where LEKRA was fairly weak, promotion of Confrontation was carried out by LKN as forcefully and as successfully as anywhere else. All this suggests that the fact that Indonesian songwriters and performers were supportive of Confrontation does not indicate any overt identification with LEKRA or its policies beyond support of the anti-Malaysia

23 LKN belonged to the left wing of the Partai Nasional Indonesia (PNI) and was, in Bodden's words, 'consigned to the "dust-bin of history"' along with LEKRA following the dawn of the New Order; see Bodden 2010:46, 58, 61. However, the PNI and the PKI had too many differences to be considered close allies. 
campaign. Nor does the listening public's appreciation for the songs that promoted Confrontation suggest support for any particular ideology. Grossberg argues that for something to be 'popular' a type of 'fandom' is required, which signifies some kind of identification. This is, however, different from 'fanaticism', which involves an ideological identification that produces identity (Grossberg 1997:6). Thus it was possible for members of the Indonesian public to enjoy songs such as Ganjang because they could relate to its main theme, but they were not relying on it, or other songs, to create their identity. Additionally, it should be noted that support for Confrontation with Malaysia was fuelled by a strong belief in Indonesia that Malaya and Singapore had assisted the regional rebellions in Sumatra and Sulawesi in 1958, thus seriously endangering the unity and stability of the country. That Britain, Australia and the USA were believed to have assisted the rebels created a further anti-imperialist argument (Mackie 1974:28-30).

Public support for Confrontation was portrayed most dramatically in a short story reported by Putra. In the story the male character is advised that he must leave at short notice for North Kalimantan. His fiancée is confused and saddened by this news, but once she realizes the nature of his mission her attitude changes and she tells him 'Please do not return until the Puppet State of Malaysia has been crushed' (Putra 2012:331). In contrast, Williams, who noted widespread condemnation of Malaysia wherever he travelled in Indonesia in 1965 , reported meeting one university lecturer who thought Confrontation was 'political idiocy'. The same man thought the price to be paid for maintaining the official ideology in terms of sacrifice of individual identity and pride was too high (Williams 1966:97-8). The lecturer appears as a lone voice against Confrontation in Williams' narrative, but Mackie (1974:88) argues that many people paid mere lip-service to the official ideology and became utterly cynical about it towards the end of the Soekarno regime's rule. In relation to Confrontation, however, it must be remembered that while Soekarno had been rendered politically impotent almost immediately following the failed so-called coup attempt of 30 September-1 October 1965, it still took until August 1966 for hostilities to officially come to an end, suggesting that Confrontation retained some popularity with the public.

\section{Conclusion}

Soekarno's policies were certainly not approved universally in Indonesia, but Soekarno was definitely a much admired figure. Soekarno was a charismatic orator with big ideas and there can be no doubt that, for many Indonesians, he 
was a great inspiration who made them proud to be Indonesian. It is very likely that the artists mentioned in this article approved genuinely of the Soekarno policies they sang and wrote about, but may have disagreed with others, such as the ban on rock and roll. Soekarno's rhetoric about NEKOLIM, for example, appears to have resounded with an Indonesian public that had endured a four-year war with the Netherlands in order to secure independence. That Malaysia had not had to fight for its independence from the British was a fact that probably made it easier for many Indonesians to accept Soekarno's assertions that Malaysian independence was not 'real' and that its creation was really a 'neo-colonial plot' designed to serve British interests, and was thus a threat to Indonesian sovereignty. The only source of information for most Indonesians at the time was the government-controlled press, and government-owned radio and television - the latter accessible to very few. People were thus exposed constantly to government propaganda, but had little with which to compare it. Soekarno could not pretend that his policies did not cause hardship to his people, but he explained that if Indonesia was to be really free of NEKOLIM intrigues it would take will-power and sacrifice. Many Indonesians seem to have accepted this, but the declining economic situation and rapid inflation in Indonesia in 1965 would have made this argument harder to sell and Soekarno's eventual demise easier to accept (Mackie 1974:202-3).

The New Order government reversed Soekarno's cultural policies soon after taking power. New Order leader Soeharto effectively took over leadership of the government in March 1966 and was officially declared president two years later, retaining the position until he stood down in 1998 — a substantially longer period than the Soekarno presidency. Throughout Soeharto's reign, the government continued the use of snappy slogans and acronyms to promote its policies. Unlike the Soekarno period, however, there was no outpouring of popular songs in support of those policies. There are many probable reasons for this. Soeharto was a strong, decisive leader, but rather a lacklustre figure compared to the charismatic Soekarno, and while Soekarno's policies were based on revolutionary rhetoric, the New Order took a more pragmatic approach, focussing on a programme of '[economic] development'. There was, thus, little of the drama of the Soekarno period available to inspire songwriters. Furthermore, the New Order regime brutally suppressed the PKI when it came to power, and songwriters and recording artists who had mentioned Soekarno policies, such as NASAKOM, in their songs may have been nervous about how they would be treated. In most cases there was no retribution, but it is likely that there was a conscious decision to discontinue the practice of putting political messages in songs, so as not to be at risk in the future. The destruction of the PKI and the ascension of the pro-Western New Order government brought an end to the 
era of revolutionary rhetoric. By the time Soeharto assumed the presidency in March 1968, the era of popular songs in support of the 'unfinished revolution' had already long ceased to be.

\section{References}

Ajoeb, Joebaar (1961). 'Luntjurkan anakpanah kedjantung kebudajaan imperialis: Laporan pleno Djuli pimpinan pusat LEKRA 1961', Laporan Kebudajaan Rakjat II, Bagian penerbitan Lembaga Kebudajaan Rakjat [no place, no date], in: Laporan umum pengurus pusat Lekra: Resolusi dan keputusan kongres nasional Lekra. Leiden: IDC. [Microfiche.]

Ajoeb, Joebaar (1962). 'Laporan umum: Konperensi nasional pertama di Bali 1962', Laporan Kebudajaan Rakjat II, Bagian penerbitan Lembaga Kebudajaan Rakjat [no place, no date], in: Laporan umum pengurus pusat Lekra: Resolusi dan keputusan kongres nasional Lekra. Leiden: IDC. [Microfiche.]

Bodden, Michael (2010). 'Modern drama, politics, and the postcolonial aesthetics of left-nationalism', in: Tony Day and Maya H.T. Liem (eds), Cultures at war: The Cold War and cultural expression in Southeast Asia, pp. 45-8o. Ithaca, NY: Cornell Southeast Asia Program.

Bowden, Tim (1987). One crowded hour: Neil Davis, combat cameraman 1934-1985. Sydney: Collins.

Department of Foreign Affairs (1963). Indonesia 1963: Looking back over the year. Department of Foreign Affairs: Republic of Indonesia.

Farram, Steven (2007). 'Wage war against Beatle music! Censorship and music in Soekarno's Indonesia', Review of Indonesian and Malaysian Affairs 41-2:247-77.

Foulcher, Keith (1969). 'A survey of events surrounding "Manikebu": The struggle for cultural and intellectual freedom in Indonesian literature', Bijdragen tot de Taal-, Land- en Volkenkunde 125-4:429-65.

Grossberg, Lawrence (1997). Dancing in spite of myself: Essays on popular culture. Durham/London: Duke University Press.

Hall, Stuart (1998). 'Notes on deconstructing “the popular"', in: John Storey (ed.), Cultural theory and popular culture: A reader, pp. 442-53. New York: Prentice Hall. [First published 1981.]

Legge, John D. (1972). Sukarno: A political biography. Sydney: Allen and Unwin.

Lindsay, Jennifer (2012). 'Heirs to world culture 1950-1965: An introduction', in: Jennifer Lindsay and Maya H.T. Liem (eds), Heirs to world culture: Being Indonesian 1950-1965, pp. 1-27. Leiden: KITLV Press.

Lockard, Craig A. (1998). Dance of life: Popular music and politics in Southeast Asia. Honolulu: University of Hawai'i Press. 
Longhurst, Brian (2003). Popular music and society. Cambridge: Polity.

Mackie, J.A.C. (1974). Konfrontasi: The Indonesia-Malaysia dispute 1963-1966. Kuala Lumpur: Oxford University Press.

Mohamad, Goenawan, edited and translated by Harry Aveling (2011). 'The "Cultural Manifesto" affair revisited: Literature and politics in Indonesia in the 196os, a signatory's view'. Monash University, Victoria: Monash Asia Institute Press. [Working Paper 134.]

Putra, I Nyoman Darma (2012). 'Getting organized: Culture and nationalism in Bali, 1959-1965', in: Jennifer Lindsay and Maya H.T. Liem (eds), Heirs to world culture: Being Indonesian 1950-1965, pp. 315-42. Leiden: KITLV Press.

Saphan, LinDa (2013). 'Norodom Sihanouk and the political agenda of Cambodian music, 1955-1970', The Newsletter 64 (Summer): 4-5.

Shuker, Roy (1994). Understanding popular music. London: Routledge.

Soedharnoto (1959). 'Laporan music. Pengurus pusat Lembaga Kebudajaan Rakjat kepada kongres nasional ke 1 LEKRA', in: Lembaga Kebudajaan Rakjat. Kongres nasional, 1st, Surakarta, 1959. Pidato2 dan laporan2. Leiden: IDC. [Microfiche.]

Soekarno (1959). Penemuan kembali Revolusi kita (The rediscovery of our Revolution); Pidato Presiden Republik Indonesia pada tanggal 17 Agustus 1959. Jakarta: Kementrian Penerangan RI.

Tan, Tjin-kie (1967). Sukarno's guided Indonesia. Brisbane: Jacaranda Press.

Toer, Pramoedya Ananta (1964). 'Kenapa kebudayaan imperialis Amerika Serikat yang harus dijebol?' Harian Rakjat, 15 March, http://www.oocities.org/ticoalu2/kenapa .html (accessed 23 May 2013).

Weatherbee, Donald E. (1966). Ideology in Indonesia: Sukarno's Indonesian revolution. New Haven, CT: Yale University.

Williams, Maslyn (1966). Five journeys from Jakarta. Sydney: Collins.

Yampolsky, Philip (1987). Lokananta: A discography of the National Recording Company ofIndonesia, 1957-1985. Madison, WI: Center for Southeast Asian Studies, University of Wisconsin. [Bibliography Series 10].

Yuliantri, Rhoma Dwi Aria (2012). 'LEKRA and ensembles: Tracing the Indonesian musical stage', in: Jennifer Lindsay and Maya H.T. Liem (eds), Heirs to world culture: Being Indonesian 1950-1965, pp. 421-51. Leiden: KITLV Press. 